\title{
DESIGN AND ANALYSIS OF BALL MILL INLET CHUTE FOR ROLLER PRESS CIRCUIT IN CEMENT INDUSTRY
}

\author{
D. Sankar prasath ${ }^{1}$, N.Venkatesh ${ }^{2}$ \\ ${ }^{I} P G$ Scholar, Department of Mechanical Engineering, Knowledge Institute of Technology, Tamil Nadu, India \\ ${ }^{2}$ Assistant. Professor, Department of Mechanical Engineering, Knowledge Institute Of Technology, Tamil Nadu, India
}

\begin{abstract}
The present work aims to design and analysis of Ball mill inlet chute along with the truck assembly for Roller press circuit UMS (Unidan Mill S) type FLS Ball mill which are used in the Cement industry for grinding clinker material. The present mill inlet chute can be used for the two compartment ball mills only in which primary and finish grinding both are takes place. It may be a closed or open circuit grinding systems.
\end{abstract}

In recent days, the Ball mill grinding systems are used with the Roller press and it is developing very fastly. The primary grinding is done by the Roller press and finish grinding takes place in Ball mill. Because of this, we can increase the Ball mill capacity as well as the Cement production. Also the feed materials which are coming from roller press to the ball mill are powdery form instead of Clinker material. The feed chute for this application requires more area to direct the material and more air allowing area to achieve the required air flow inside the mill to transmit the grounded material.

The replacement of the liner plates/mill components and access during maintenance is difficult in the present UMS mills since the mill inlet is fixed with the foundation. This can be avoided by implementing the new designed movable truck assembly at inlet chute. In this design, the Inlet chute will be fixed on the movable truck assembly which can be easily removable along with chute during the maintenance and liner plate replacement. The main objective of this project is to identify and design the suitable inlet chute for the BM+RP mill circuit with feed chute truck assembly. The designed chute's flow characteristics will be analyzed by using DEM software. For designing and analyzing the Roller press circuit Ball mill chute, UMS 4.6m diameter, RP+BM (Roller press + Ball Mill) Circuit Cement Ball mill feed materials and its properties are taken.

Keywords: ball mill, roller press, cement industry

\section{BALL MILL IN CEMENT INDUSTRY}

The Cement production is certainly the most important for all dry grinding applications around the world. The estimate for the world energy consumption for cement production is 18.7 Tons Watt-hour (TWh) which is approximately $0.02 \%$ of total world energy consumption per year. The world consumption of cement was about 1.72 billion tonnes in 2002 and it is increasing at about $1 \%$ per annum. Cement production process typically involves:

$>$ Grinding limestone and other raw materials to achieve the right chemical composition in a dry circuit, making cement by the chemical reaction between the components of the ground mixture.

$>$ This chemical reaction occurs at high temperature in a rotary kiln grinding the cement clinker nodules. Grinding occurs at the beginning and the end of the cement making process. Approximately 1.5tonnes of raw materials are required to produce 1 ton of finished cement.

$>$ The electrical energy consumed in the cement making process is in order of $110 \mathrm{kWh} /$ tonne and about $30 \%$ of which is used for the raw materials preparation and about $40 \%$ for the final cement production by cement clinker grinding. Production costs and environmental concerns are emphasizing the need to use less energy and require design updating in the ball mill components.

For most of the twentieth century, the dry grinding circuits for the production of finished cement from cement clinker consist of two-compartment tube mills and the air separators. It is not uncommon to produce the cement in an open circuit. Advances in cement grinding technology are slow and these advances are limited to more developed countries. Approximately 95\% of the feed to the cement grinding circuit are clinker and the rest of the feed are "additives" which includes grinding aids.

The quality of cement is measured by the surface area or the Blaine index. The unit of the Blaine index is $\mathrm{m} 2 / \mathrm{kg}$, and this index is determined by the Blaine air permeability test. The surface area of the cement powder depends on size distribution of cement particles; smaller particles have larger surface area. If the particle size distribution is known, the Blaine index can be successfully predicted (Zhang and Napier-Munn, 1995). The cement clinker grinding circuit reduces the feed from $80 \%$ passing size between 10 and $20 \mathrm{~mm}$ to $100 \%$ passing $90 \mathrm{microns}$.

The size reduction takes place in a two compartment tube mill; the first compartment of the mill is shorter than the 
second compartment. The coarse clinker is ground in the first compartment where larger balls $(80,60,50 \mathrm{~mm})$ are used and the fine grinding is done in the second compartment where smaller balls (below 25mm) are used. A diaphragm separates the two compartments and allows only particles below a certain size to pass to the second compartment.

Ground material exits the mill through the discharge grate which prevents grinding balls from leaving the mill. A proportion of material, mostly fines, is "air swept" out of the mill. The final product is the fine fraction of the air classifier and the coarse fraction returns to the mill. In the past 20 years, high press American and European cement grinding circuits have High Pressure Grinding Rollers (HPGR) which increases grinding capacity and energy efficiency.

The idea of this project is to design the feed chute for Roller press ball mill (RP+BM) circuit with feed chute truck assembly to reduce the maintenance time as well as to improve the production of cement. The present work is aimed at further understanding of the design studies of feed chute for powdery feed material and truck using FEM and DEM software and to use in the further designs of ball mills.

\subsection{FLS UMS Type Cement Ball Mill}

In 1893 FLSmidth (FLS) firm acquired the rights to a new mill type, the tube mill, from the French/Danish inventor. After being thoroughly redesigned and refined, the tube mill influenced the cement industry in the coming century. Fredrik used the compass and ruler to redefine the tube mill. After being thoroughly redesigned and refined, the tube mill became so popular that it was sold all over the world already before the turn of the century.

Ball mills (Fig 1.1) are coming in cement plant areas of raw grinding, coal grinding and cement grinding which in turn as raw mill, coal mill and cement mill. Ball mills are horizontal tube mills having single or two compartments for grinding, Balls as grinding media and driven by side or central drive.

The designation UMS is an abbreviation of the old FLS trade name Unidan Mill with an added $\mathrm{S}$ for slide shoe bearings. The UMS mill type was developed around 1983, and the reason was a demand for increased ventilation of cement mills.

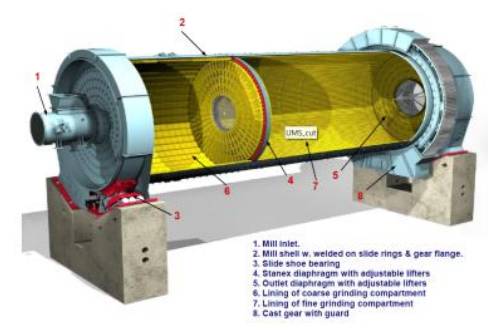

Fig 1.1 Ball mill View

To meet this target, the formerly used trunion bearings were substituted by slide shoe bearings, allowing high ventilation at at low pressure drop across the mill. Also the in- and outlet as well as the diaphragm were redesigned.

At the same time a number of other improvements in respect of mechanical design and lay-out were incorporated in the new mill type. Following improvements are high-lighted:

$>$ Heavy steel castings for trunions and mill heads are substituted by welded-in slide rings, resulting in a more "healthy" design in respect of transformation of the forces to the bearings.

$>$ Expensive and complicated assemblies with tight fitting bolts are eliminated.

$>\quad$ Reduced over-all mill length giving lower building costs than for mills with trunion bearings.

$>$ Lower machinery price and shorter delivery time due to the all-fabricated design.

As for the diaphragm, the outlet grate is provided with wear resistant chromium cast steel grates, bolted to the structural parts as well as adjustable lifters for optimising the material level in the last compartment. The nominal width of the slots is the same as in the diaphragm, but to avoid clogging, the diaphragm slots are specified with minus tolerances whereas the slots in the outlet grate are specified with plus tolerances. The centre openings in both the diaphragm and in the outlet grate are optimized to the cross sectional profile of the maximum allowed ball charges during operation. Since the centre distance to the charge is considerably larger during operation than when the mill is stopped it is possible to use a larger centre radius than the centre height of the ball charge with the mill stopped. Of course, due to the large openings some grinding balls will drop into the diaphragm when the mill stops, but special internal lifters will return these balls when the mill is restarted.

The large centre openings in the diaphragm and in the outlet contribute to an over-all very low pressure drop across the UMS mills.

\subsection{Principle of Operation}

In ball mill, ball has to be charged around $30-32 \%$ in first and second compartments. Balls are in the range of $50-90 \mathrm{~mm}$ in coarse and $15-50 \mathrm{~mm}$ in fine grinding. Grinding of material takes place by means of collision or attrition or tumbling action takes place between the balls and the charge.

The height from the Center of the mill to the surface of the ball is called the "center distance". And the height from the top of the mill inside diameter to the surface of the charge is called the "free height". Loading of material allows in free height only. When the mill is in running condition, center of the mill consider as a arm and the charge displaced at certain angle. 


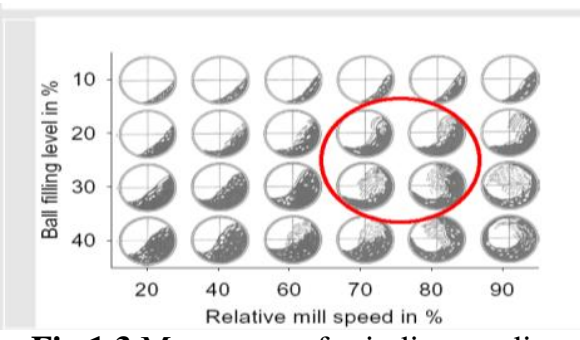

Fig 1.3 Movement of grinding media

Critical speed is the speed at which the centrifugal force is equal to the gravitational force. Normal mill speed is 70 to $80 \%$ of the critical speed (Fig 1.3). For example if the critical speed is $18 \mathrm{rpm}$, mill speed will be $15 \mathrm{rpm}$. If your mill speed is more than the critical speed and the centrifugal action > gravitatinal action all the ball charges are sticking in to the mill surface and there will be no attrition or collision action takes place between the ball \& the charge (Fig 1.5). The ball will not fall. The balls and charges are simply riding over the roof of mill.

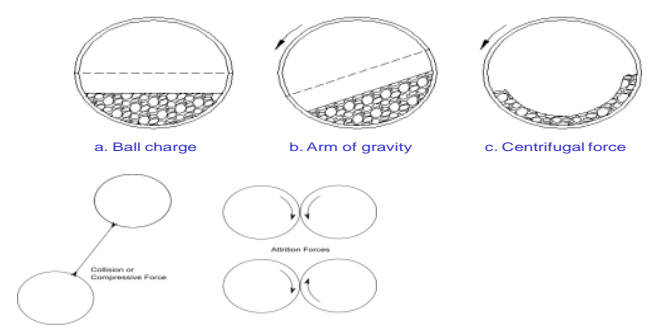

Fig 1.4 Principle of operation

Trunnion bearing mills having mill heads \& trunnion that is heavier steel castings, combidan diaphragm and outlet end with screen plate. This mill is having less ventilation and the diaphragm is not able to controlling the material flow. Earlier most of the mills in open-circuit, now cement plants converting to close circuiting by incorporating changes in the mill internals of liners, stanex diaphragm and outlet diaphragm including separators, fans and bucket elevators.

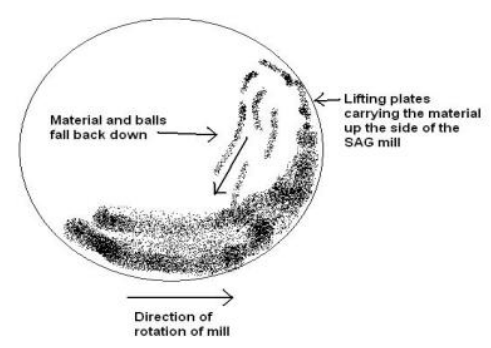

Fig 1.5 Material flow inside mill

\section{AIM AND METHODOLOGY}

The present work aims to design and analysis of Roller press circuit Ball mill inlet chute along with the truck assembly for Roller press circuit UMS (Unidan Mill S) type FLS Ball mill which are used in the Cement industry for grinding clinker material. The present mill inlet chute can be used for the two compartment ball mills only in which primary and finish grinding both are takes place. It may be a closed or open circuit grinding systems.
The feed materials which are coming from Roller press to the ball mill are powdery form instead of Clinker material since the primary grinding done by Roller press. The feed chute for this application requires more area to direct the material and more air allowing area to achieve the required air flow inside the mill to transmit the grounded material.

The replacement of the liner plates/mill components and access during maintenance is difficult in the present UMS mills since the mill inlet is fixed with the foundation .This can be avoided by implementing the new designed movable truck assembly at inlet chute. In this design, the Inlet chute will be fixed on the movable truck assembly which can be easily removable along with chute during the maintenance and liner plate replacement.

The main objective of this project is to identify and design the suitable inlet chute for the BM+RP mill circuit with feed chute truck assembly. The designed chute's flow characteristics will be analysed by using Discrete Element Method (DEM) software.

For designing and analysing the Roller press circuit Ball mill chute, UMS 4.6 diameter and $15 \mathrm{~m}$ length Cement Mill (RP+BM Circuit) feed materials and its properties are taken for chute area and air opening area calculations.

The designed mill inlet chute should be analyzed using FEM and DEM softwares and finally the prototype is to be prepared and it should be tested. The following methodology is followed in this project work:

$>$ Study of existing mill inlet chute presently using in two compartment mills.

$>$ Data collection of required parameters based on application

$>$ Require mill chute area and Air opening area calculation for powdery material

$>$ Design of Inlet chute and truck assembly for ball mill.

$>$ Selection of supports for truck assembly.

$>$ Stress, strain, FOS and displacement analysis of truck frame assembly by using 3D software.

$>$ FEA Analysis for chute design validation.

$>$ DEM Analysis for chute flow characteristics

$>$ Foundation load and Vibration studies of mill inlet chute

$>$ Preparing and Testing of proposed inlet chute model

$>$ Comparison of DEM analysis \& Test results

$>$ Conclusion based on the results.

\section{BALL MILL INLET CHUTE}

The purpose of the stationary inlet is to direct the materials (clinker, Gypsum, additives and material recirculated from the separator) and the required air flow is adjusted by means of the damper. The feed chute is lined with bolted-on wear plates. The damper in the air intake is adjusted manually during the running-in of the mill. 
A new inlet to the mill was introduced for two chamber mill in the beginning of 2001 at FLS. The old inlet was designed to meet a demand for very high mill ventilation, but when this demand turned out to be less important we decided to update the old inlet to achieve a longer service life, less risk for back spillage, etc.

Experiences from the old inlet has been used in the design work and the new mill inlet is sized for sufficient mill ventilation at a low pressure drop and the duct for material is equipped with wear resistant composite plates. A hand operated built-in damper allows adjustment of the pressure at the mill inlet.

A modified design of this type of inlet is used for hot drying gas directly to the grinding chamber or to a drying chamber bolted-on to the web plate on the inlet slide ring. The inlet for hot gas is equipped with seal to the rotating mill. Disadvantages of the existing mill inlet chute for Roller press circuit:

$>\quad$ Can be used only for clinker material.

$>$ During maintenance, the Mill inlet chute has to be removed. Additional tools required

$>$ It will increase the plant off time

$>$ Increasing Man hours and manpower

$>$ Liner replacement, bolt tightening will be complicated

\subsection{Inlet Chute Design Considerations}

The following parameters are considered while designing the mill inlet chute for powdery materials.

$>$ UMS $\varnothing 4.6 \mathrm{~m}$ Cement mill

$>\quad$ It is the mostly sold mill in FLS-DK and FLS-INDIA

$>$ Standard Inlet duct size for 4.6m mill: $\varnothing 1000 \mathrm{~mm}$

$>$ Project Reference: Prism Cements Limited, SatnaMadhya Pradesh and Chettinad Cements Ltd, KallurKarnataka.

$>$ The material used for chute is ASTM A36 and thickness is $5 \mathrm{~mm}$.

$>\quad$ The wear plate is Hardox material $5 \mathrm{~mm}$ thick overlay on $8 \mathrm{~mm}$ thickness mild steel plate which protects the chute from the abrasive material like cement clinker.

\subsection{Mill Speed Calculation for UMS Ø4.6m Mill}

For this project work $4.6 \mathrm{~m}$ diameter UMS cement mill is considered. The mill speed is calculated from the critical speed. At critical speed there is grinding takes place. Commonly the Ball mill speed is calculated as $77 \%$ of the critical speed.

Mill liner thickness $=40 \mathrm{~mm}=0.04 \mathrm{~m}$

Mill speed $=77 \%$ of the critical speed

Critical speed $(\mathrm{Nc})$ is the speed at which the centrifugal force is equal to the gravitational force.

$$
\mathrm{Nc}=42.3 / \mathrm{D} 1 / 2
$$

$\mathrm{D}$ is the effective diameter of mill $=$ Mill diameter - Liner thickness

$=4.6-(0.04 \times 2)=4.52 \mathrm{~m}$

$\mathrm{Nc}=42.3 / 4.521 / 2=19.89 \mathrm{rpm}$

Mill speed $=0.77$ x $19.89=15.33 \mathrm{rpm}$

So the mill speed is $15.33 \mathrm{rpm}$ for $\varnothing 4.6 \mathrm{~m}$ UMS mill.

\subsection{Material Selection}

The materials are selected based on the truck assembly used in the Minerals grinding mills and previous references/experiences. The following materials are considered for designing the chute and truck assembly:

$>$ Frame - ASTM A36

$>$ Shaft - DIN 668 Standard

$>$ Wheel - ASTM A 36 and Brass Bushing.

$>$ Inlet chute - ASTM A36

$>$ Inlet chute Wear plates - Hardox material

\section{INLET CHUTE CALCULATIONS}

The require chute area and air opening area for powdery material was calculated and compared with the existing chute design values. The results shows that the existing chute is not capable for powdery material and had very less chute area and air opening area which is less than the requirement.

\subsection{Mill Chute Area Calculation}

The following criteria must be considered while sizing the ball mill inlet chute:

$>$ The dimensions/areas for a chute should as far as possible be chosen according to

$>$ the outlet flange for a machine.

$>\quad$ The smallest side length in a chute must be min. 5 times the max lump size.

$>$ Min. chute size for lumpy material: $250 \mathrm{~mm} \mathrm{x}$ $250 \mathrm{~mm}(0,063 \mathrm{~m} 2)$. Min. chute size for powdery material: $\varnothing 200$ (0.04 m2).

$>$ The minimum free area of a chute should be calculated on the basis of a velocity of $1 \mathrm{~m} / \mathrm{sec}$, and the chute being $25 \%$ full for powdery material and $50 \%$ full for lumpy material.

$$
\mathrm{A}=\mathrm{Q} \times 100 /(3600 \times \mathrm{V} \times \mathrm{F}) \mathrm{m} 2
$$

Where,

$\mathrm{Q}=$ Volume flow rate in $\mathrm{m} 3 / \mathrm{hr}$

$\mathrm{V}=$ Velocity in $\mathrm{m} / \mathrm{sec}$

$\mathrm{A}=$ Cross sectional area in $\mathrm{m} 2$

$\mathrm{F}=$ Filling percentage in $\%$

Feed materials:

Clinker $=772 \mathrm{t} / \mathrm{hr}$

Dry flyash $=116 \mathrm{t} / \mathrm{hr}$

Gypsum $=36 \mathrm{t} / \mathrm{hr}$

Performance enhancer $=28.5 \mathrm{t} / \mathrm{hr}$

Area Required for Clinker:

Total material flow to mill inlet is $772 \mathrm{~T} / \mathrm{hr}=772000 \mathrm{~kg} / \mathrm{hr}$ [Mass flow rate from PD and mass flow diagrams]

Clinker bulk density from mass flow diagram $=1.2 \mathrm{~T} / \mathrm{m} 3$ 
$\mathrm{Q}=\mathrm{m} / \mathrm{p}[\mathrm{m}=$ mass flow rate in $\mathrm{kg} / \mathrm{hr}$ and $\mathrm{p}=$ density in $\mathrm{kg} / \mathrm{m} 3] \quad=772000 / 1.2 \times 10^{\wedge} 3$

$$
\mathrm{Q}=643.3 \mathrm{~m} 3 / \mathrm{hr}
$$

As per the chute design formula, the minimum free area of chute should be calculated on the basis of Velocity $1 \mathrm{~m} / \mathrm{sec}$ and Chute being 25\% full for powdery material [50\% in case of lumpy material]

$\mathrm{A}=\mathrm{Q} \times 100 /(3600 \times \mathrm{V} \times \mathrm{F})$ in $\mathrm{m} 2$

$=643.3 \times 100 /(3600 \times 1 \times 25)$

$\mathrm{A}=0.715 \mathrm{~m} 2$ [minimum area required for Clinker]

Similarly, Area for dry fly ash $(0.184 \mathrm{~m} 2)$, gypsum (0.044 $\mathrm{m} 2)$ and Performance Enhancer $(0.035 \mathrm{~m} 2)$

[Dry Fly ash 116 tph@0.7 T/m3, gypsum 36tph@0.9 T/m3 and Perf.enhancer 28.5tph @0.9 T/m3 are considered]

Total minimum chute Area required $=0.715+$ $0.184+0.044+0.035=0.978 \mathrm{~m} 2$

But the existing chute minimum area at neck portion is 0.29 $\mathrm{m} 2$ which is very less. Hence the redesigning is required for the powdery/roller-pressed clinker $\&$ which is essential for the higher production.

\subsection{Air Flow Opening Area Calculation}

In ball mill, the grounded cement materials are transported by means of air flow inside the mill. The induced draft fan sucks the gas with dust particles and the dust is collected in the ESP and cleaned air sent through the chimney.

From Process Diagram Fig 3.1, [Prism Project Considered]

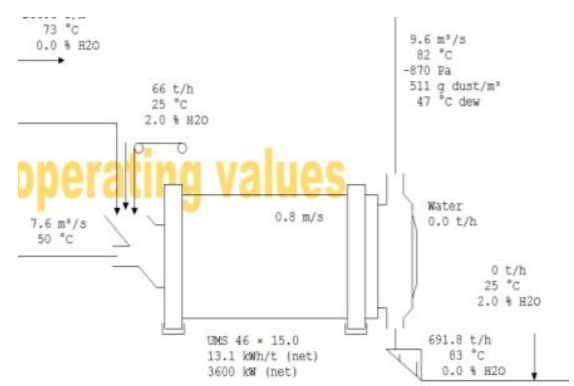

Fig 3.1 Ball mill flow sheet

Quantity of Air $=7.6 \mathrm{~m} 3 / \mathrm{sec}$

Velocity of Air $=20 \mathrm{~m} / \mathrm{s}$ [standard for cement ball mill]

Flow rate $\mathrm{Q}=\mathrm{A} \times \mathrm{V}$

$\mathrm{A}=\mathrm{Q} / \mathrm{V}=7.6 / 20=0.380 \mathrm{~m} 2$

$\mathrm{A}=3,80,000 \mathrm{~mm} 2$

Actual area as per the existing chute is $371700 \mathrm{~mm} 2$.

Hence the Opening area for Air flow is $371700 \mathrm{~mm} 2$ which is very much less than the minimum requirement of $380000 \mathrm{~mm} 2$.

\section{FEED MATERIAL PROPERTIES}

The feed material used in the Roller press circuit mill was taken for the designing of the new mill inlet chute for powdery material.

Product: PPC Cement with $275 \mathrm{t} / \mathrm{h}$ output \& $360 \mathrm{~m} 2 / \mathrm{kg}$ Blaine

Feed proportions used in Prism Cement are: Clinker $=65 \%$, Gypsum $=5 \%$, Dry Fly ash $=24 \%$ and Semi-dry fly ash $=6 \%$

\subsection{Ball Mill feed materials}

The table 3.1 provides the feed materials properties like feed size, bulk density, moisture content, Angle of repose and abrasiveness.

Table 3.1 Feed Material Properties

\begin{tabular}{|l|l|l|l|l|l|}
\hline Material & Feed size in min & $\begin{array}{l}\text { Bulk density in } \\
\text { mech. conveyors } \\
{\left[\mathbf{t}^{3} \text {, dry basis }\right]}\end{array}$ & $\begin{array}{l}\text { Design moisture } \\
{[\%, \text { wet basis }]}\end{array}$ & $\begin{array}{l}\text { Angle of } \\
\text { repose } \\
{\left[{ }^{2}\right]}\end{array}$ & $\begin{array}{l}\text { Abrasiveness } \\
{[\text { low, medium }} \\
\text { or high }]\end{array}$ \\
\hline Limestone & 100 & 1.40 & 12.0 & 38 & low \\
\hline Laterite & 50 & 1.20 & 8.0 & 38 & high \\
\hline Gypsum & 50 & 0.90 & 8.0 & 40 & low \\
\hline Raw mill feed & 100 & 1.40 & 12.0 & 38 & low \\
\hline Raw meal & $15 \%+90 \mu$ & 0.90 & 1.0 & NA & low \\
\hline Clinker & 40 & 1.20 & 0.0 & 35 & high \\
\hline Kiln Feed & $15 \%+90 \mu$ & 1.00 & 1.0 & NA & low \\
\hline Coal & 60 & 0.80 & 20.0 & 38 & low \\
\hline $\begin{array}{l}\text { Roller pressed } \\
\text { clinker }\end{array}$ & - & 1.50 & - & 40 & high \\
\hline Gypsum to mill & 35 & & & & \\
\hline
\end{tabular}

\subsection{Chute Design Parameters}

While designing the chute the following important parameters are needs to be considered:

$>\quad$ Type of materials handled by the chute

$>$ Moisture content during operation

$>$ Inclination angle require for the effective flow of material

$>$ Abrasiveness factor

$>$ Require chute thickness

$>$ Wear resistant plate thickness

All these parameters are tabulated in the table 3.2 which has to be considered for designing the inlet chute. FLS standard parameters for various materials has tabulated below.

Table 3.2 Chute design parameters 


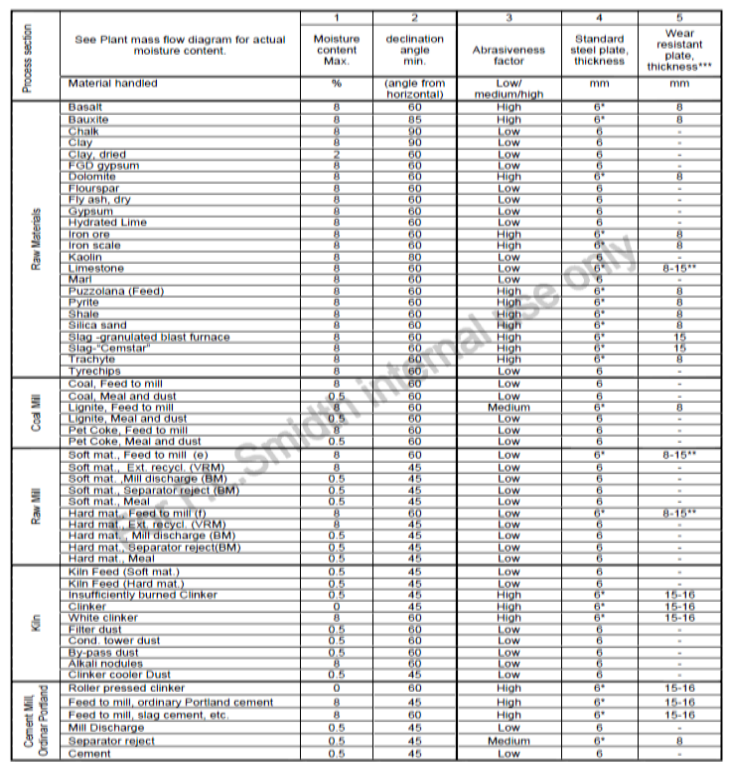

\subsection{Support for Truck Frame}

\subsubsection{Buckling Load Calculations}

\subsubsection{Crippling Load or Buckling Load}

In case of Short column, which fails by crippling load at failure equals $\mathrm{P}=\mathrm{Fc} \times \mathrm{A}$ where $\mathrm{Fc}=$ Crushing stress and $\mathrm{A}=$ Cross-sectional area.

But for Long column which fails by buckling of load at failure is given by PE (Euler's load)

$\mathrm{P}=$ Crippling load $/\left[1+\alpha(\mathrm{L} / \mathrm{K})^{2}\right]$

$=\mathrm{Fc} \mathrm{A} /\left[1+\pi^{2} \mathrm{E}(\mathrm{L} / \mathrm{K})^{2}\right]$

Where $\mathrm{Fc}=$ Crippling stress and $\mathrm{A}-$ Area, $\alpha=\pi 2 \mathrm{E}$

Crippling load $=\mathrm{P}=\pi^{2} \mathrm{El} / \mathrm{L}^{2}=\pi^{2} \mathrm{E} \mathrm{A} \cdot \mathrm{k}^{2} / \mathrm{L}^{2}$

Stress at failure $=\mathrm{P} / \mathrm{A}=\pi^{2} \mathrm{E} /[\mathrm{L} / \mathrm{K}]^{2}$

Where $\mathrm{L} / \mathrm{K}=$ Slenderness ratio

From above, it can be realized that stress at failure P/A according to the formula will be higher when the slenderness ratio is small. But this stress at failure cannot be greater than the crushing stress for the same material.

$\mathrm{P} / \mathrm{A}=\pi^{2} \mathrm{E} /[\mathrm{L} / \mathrm{K}]^{2}$

$\mathrm{Pcr}=\pi^{2} \mathrm{El} / \mathrm{L}^{2}$ (Least moment of inertia)

The various sections buckling load, safe load and stresses were analyzed for the same dimensions and results were tabulated.

\subsubsection{Support Selection for Frame}

The base frame for truck assembly was selected based on the results obtained.

The shear stress, Bending stress (Table 4.2), Buckling load and Safe load (Table 4.1) were calculated and tabulated. Force acting taken as $10 \mathrm{kN}$ and length taken as $1000 \mathrm{~mm}$ for the calculation.
Table 4.1 Buckling Load and Safe Load

\begin{tabular}{|l|l|l|l|}
\hline S.No & Description & $\begin{array}{l}\text { Crippling/ Buckling } \\
\text { Load Pcr in kN }\end{array}$ & $\begin{array}{l}\text { Safe Load } \\
=\text { Pcr / FOS }\end{array}$ \\
\hline 1 & PE Parallel flanged beam & 82.38 & 20.5 \\
\hline 2 & HEB Parallel flanged beam & 865.31 & 216.32 \\
\hline 3 & UNP beams & 134.72 & 33.68 \\
\hline 4 & Square Hollow Section & 1212.4 & 303.12 \\
\hline 5 & Hollow circular section & 721.34 & 180.33 \\
\hline
\end{tabular}

Table 4.2 Shear and Bending stress

\begin{tabular}{|l|l|l|l|}
\hline S.No & Description & Bending Stress $\sigma$ in N/mm2 & $\begin{array}{l}\text { Shear Stress } \tau \max \\
\text { in N/mm2 }\end{array}$ \\
\hline 1 & PPE Parallel flanged beam & 73.09 & 27.6 \\
\hline 2 & HEB Parallel flanged beam & 27.77 & 46.29 \\
\hline 3 & UNP beams & 66.48 & 11.44 \\
\hline 4 & Square Hollow Section & 53.41 & 9.8 \\
\hline 5 & Hollow circular section & 89.79 & 16.55 \\
\hline
\end{tabular}

Based on the above results the bending stress and shear stress is low in square hollow section and safe load is higher than other beams. Since the square hollow section is selected for the support frame design.

\subsection{Design and Analysis of Frame}

The Inlet chute was designed based on the calculated minimum requirement of chute area and Air opening area. The chute model has done in SOLIDWORKS software. The Flow characteristics by Discrete Element Method (DEM) and analysis of new designed chute to be done.

\subsubsection{Feed Chute Model}

The feed chute model (Fig 5.1) was prepared in 3D software based on the calculated details. The below model shows the chute for powdery material.

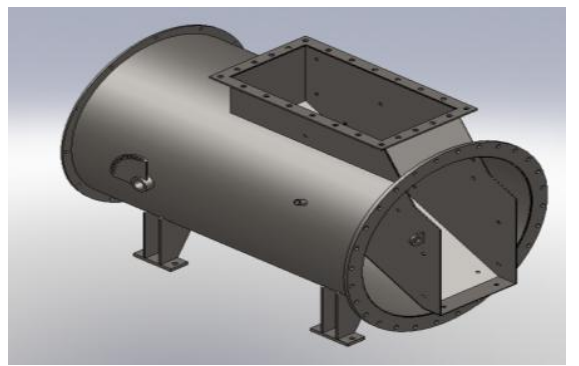

Fig 5.1 Feed chute model

\subsection{Design of Truck Frame}

\subsubsection{Feed Chute Truck Model}

Feed chute truck assembly is used in the minerals (grinding of ore of copper, Al, Steel, gold, etc..,) ball mill. So the minerals feed chute truck assembly is taken as reference to implement in the UMS mills feed chute with the design optimization.

The designed new truck for mill inlet chute for UMS ball mill model as given below (Fig 5.2). The hollow square section was used as supports in all the sides of the truck frame.

\subsubsection{Feed Chute with Truck Assembly}


The typical assembly of feed chute with truck assembly was created in 3D software. The final truck model is used in this assembly model. But the Feed chute is not finalized. It needs optimization and will be completed in next phase of project.

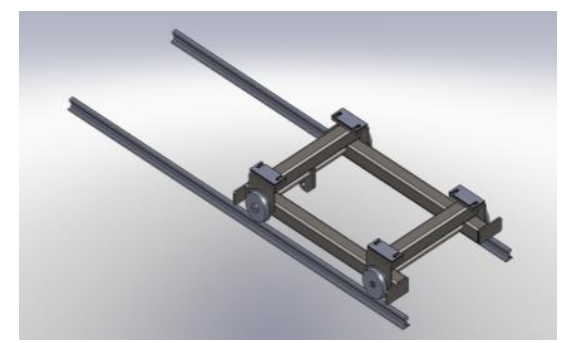

Fig 5.2 Feed chute truck model

There are four square sections are used in the feed chute track assembly. The material ASTM A36 is used for truck and the chute.

Truck assembly model with feed chute as shown in fig 5.3

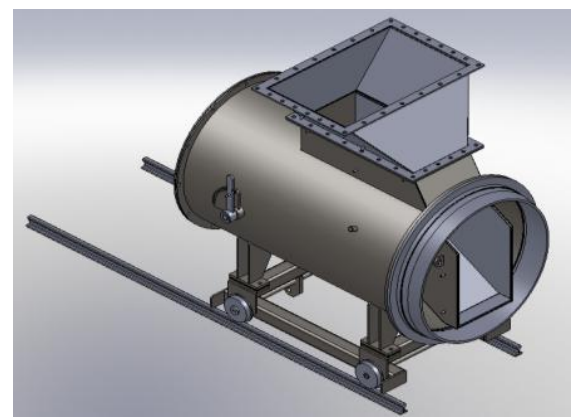

Fig 5.3 Feed chute with truck assembly

Front view of Truck assembly model with feed chute as shown in the below fig 5.4.

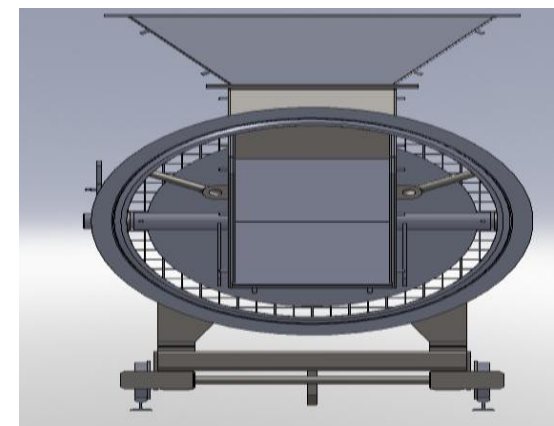

Fig 5.4 Front View of truck assembly

\subsection{Analysis of Truck Frame}

The truck frame was analyzed by using the Solid Works software. The force acting on the truck frame has taken as $10 \mathrm{kN}$.

The Stress analysis of truck frame as mentioned below (Fig 5.5)

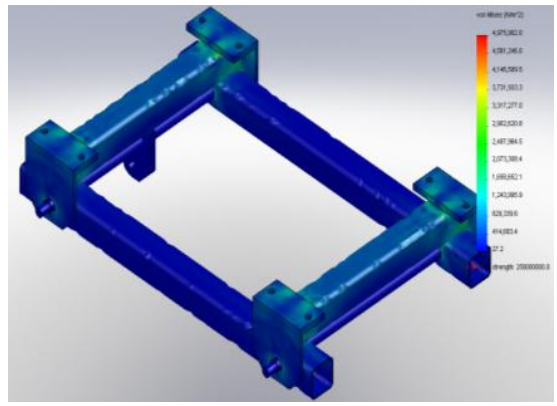

Fig 5.5 Stress analysis of frame

The displacement value from the analysis is very minimum (fig 5.6)

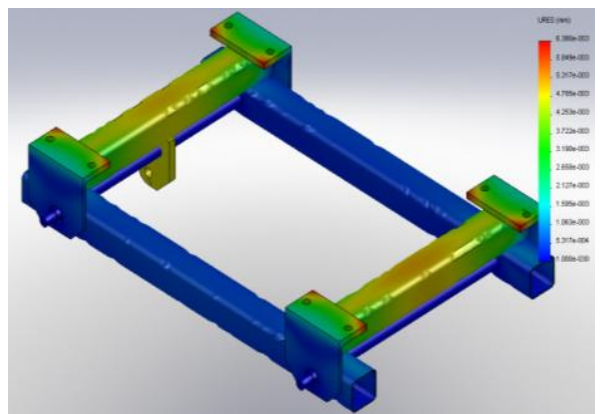

Fig 5.6 Displacement analysis of frame

The strain on the frame is analyzed by the software and the results shown below (Fig 5.7)

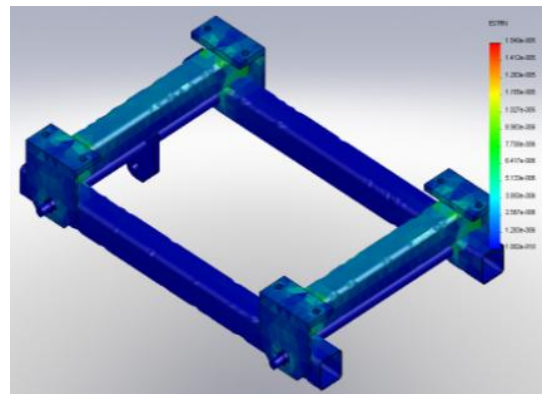

Fig 5.7 Strain analysis of frame

The FOS of the frame is analyzed by the software and the results shown in Fig 5.8

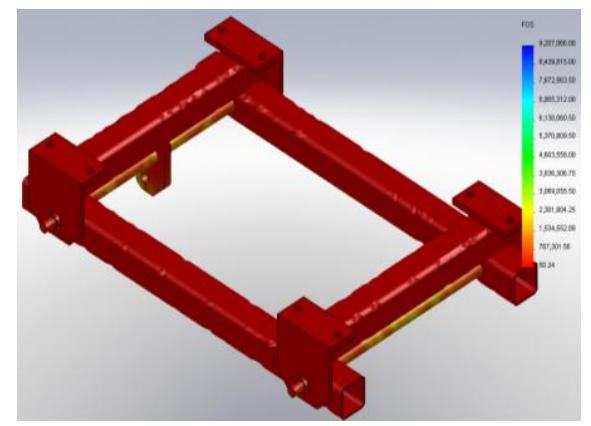

Fig 5.8 FOS of frame

\section{RESULTS \& DISCUSSION}


The feed chute truck is analyzed using the Solid works software. The following properties are analyzed for the truck frame.

$>$ Stress on the truck frame.

$>$ Strain on the truck frame.

$>$ Displacement of the truck frame.

$>$ Factor of Safety of the truck frame.

The results are tabulated in the table 5.1.

Table 5.1 Stress and displacement analysis

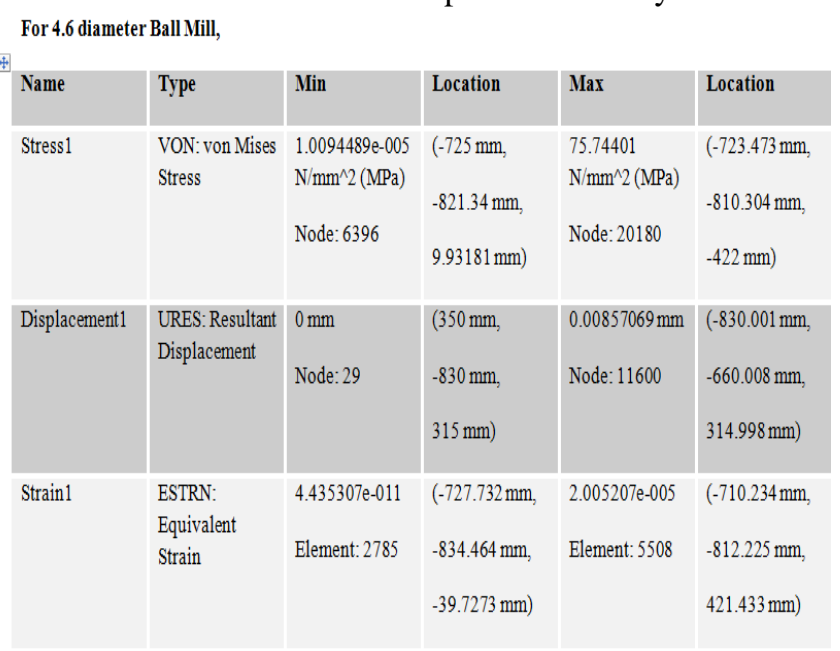

From the above results, the minimum stress obtained as 75 $\mathrm{N} / \mathrm{m} 2$ which is very low compared to the allowable stress 165 $\mathrm{N} / \mathrm{mm} 2$. Since the factor of safety is about 4.5 .

The designed truck assembly will be used for the further work in future.

\section{FUTURE WORK TO BE DONE}

The truck frame assembly was designed, optimized and finalized in this project. The chute model was done in $3 \mathrm{D}$ software for the calculated chute area and opening area for air flow.

The future work includes the following activities:

$>$ By using Discrete Element method, the flow properties need to be checked and analyzed. If require the chute has to be redesigned.

$>$ Vibration analysis has to be done.

$>$ Prototype model for new designed Inlet chute has to be prepared and tested.

$>$ Foundation load calculations for the new chute design needs to be calculated.

\section{REFERENCES}

[1]. Parbery R.D. and Roberts A.W., (1986) 'On equivalent friction for the accelerated gravity flow of granular materials in chutes', Powder Technology, Volume 48, Issue 1, September 1986, Pages 75-79.

[2]. Santomaso A.C. and Canu P, (2001) 'Transition to movement in granular chute flows', Chemical Engineering Science, Volume 56, Issue 11, June 2001, Pages 3563-3573.
[3]. Gonzalez C.A and Chanson.H, (2008) 'Turbulence manipulation in air-water flows on a stepped chute: An experimental study', European Journal of Mechanics B/Fluids, Volume 27, Issue 4, July-August 2008, Pages 388408.

[4]. 'Concrete stepped blocks for chute spillways', (1990) Construction and Building Materials, Volume 4, Issue 4, December 1990, Pages 218-219.

[5]. Kristian Kramer and Willi H. Hager., (2005) 'Air transport in chute flows', International Journal of Multiphase Flow, Volume 31, Issues 10-11, October-November 2005, Pages 1181-1197.

[6]. FLSmidth Pvt. Limited's Chute design manual.

[7]. Herbst J.A and Nordell L., (2001) 'Optimization of the design of SAG mill internals using simulation', Vol 4., University of British, Columbia Pages 150-164.

[8]. Rajamani R.K. and R.K. Mishra, (1992, 1994 \&2000) 'Discrete Element Analysis of Tumbling mills', Powder tech 109 (1-3), Pages 105-112. 